H. F. Dovaston (pp. 249-253). It is P. Lolii, and is possibly the perithecial form of Helminthosporium siccans. Other new species are described by N. C. Preston (pp. 271-276)-Myrothecium jollymannii from dried tobacco leaves in Nyasaland, and $M$. striatisporyen from clay soil in New Zealand.

\section{Establishment and Care of Lawns}

AMONG the more gereral matters dealt with in a recent iqsuelof Journal of the Board of Greenkeeping feseal 17, No. $24 ; 1948)$ are papers on the cgralidation of lawn surfaces by bitumen, and a useal review of methods of earthworm control on lawns. R. B. Dawson and J. R. Escritt describe the method of stabilizing the surface of lawns by the application of sand and bitumen emulsion immediately after the grass seeds are sown. The treatment can also be applied to established turf. Lawn surfaces were much improved, and the process may be useful for small areas subject to heavy wear. Detrimental effects were not very marked, but the establishment of bent and timothy grasses was reduced. J. R. Escritt and J. H. Arthur review the methods available for earthworm control. Many species of earthworm do not form casts, and therefore are not a nuisance, but only help in aeration and soil mixing. Organic manures generally stimulate earthworm activity, while the presence of a turf 'mat' diminishes the production of unsightly casts. Factors of management and manuring are therefore important. The relative merits of mowrah meal, copper sulphate, potassium permanganate, derris, mercuric chloride, lead arsenate and other control substances are discussed and provide a very useful advisory review of this patter.

\section{Sugaril Beet Viruses}

THE virus of sugar beet yellows has not hitherto been regarded as o. al-borne. Phyllis E. M. Clinch and J. P. I r inan have shown, however (Sc. Proc. Dub. S\&. 24 No. 27 ; July 29, 1948), that seed of a f. far fily of sugar beet (No. 41), when germinated, gives a considerable percentage of yellowed seedlings. The identity of this yellowing with sugar beet yellows is somewhat by implication; but the symptoms and physiological effects are similar. The paper also describes two types of yellows disease from commercial sugar beet crops in Eire. Sugar beet yellows is probably the most serious disease of this crop in England. R. Hull and Marion Watson have a useful paper in the Journal of Agricultural Science (37, Part $4,301-310 ; 1948$ ) on the relation of nutrition and variety with severity of yellows. Manurial treatments in general increase the yields of roots and sugar; but the losses caused by infection unfortunately increase proportionately as the mean yields increase. Fertilizers have little effect in varying the symptoms of the disease. Commercial varieties and some breeders' lines were tested for possible tolerance of the vints ; but no useful indication of this was obtained. Norwegian Strandflat

IN a paper in the Geographigal Journal of January on the "Gegmorphology Norway", Prof. K. M. Strom ropurn to the folic of the strandflat, a topic which halfovoked much controversy in past years. H hoves that mine abrasion is much in evidence, tholgh prie gacier abrasion has played its part. The lov piacuts across fjord deeps and corrie lake deeps, wd though local glaciers have certainly played a notable part, it is in the main due to marine abrasion. Prof. Ström cites the example of Moskenesöy, which has practically no strandflat on the inner or sheltered side, but has an abrasion platform $8 \mathrm{~km}$. broad on the exposed side. The tendency to stress glacial action in the formation of the strandflat is probably due to the study of the strandflat where it shows a hummocky appearance through an overflow by ice during the last glaciation. The main features of the strandflat seem to have been abraded at successively lower levels since early Miocene times up to late Pliocene; this has been followed by excavation by glaciers from the inland ice and corrie glacier erosion and, finally, post-glacial marine abrasion in the peripheral areas where changes of level due to isostatic recovery have been least. Earthquakes during January
Fourteen tro earthquakes occurred in various
parts of the the during January. The strongest wey thas on January 23, 24 and 27, with epicentres in the Indian Ocean (about 600 miles south-west of Sumatra), near the Tonga Islands, and in New Britain respectively. Three earthquakes had deeper foci than is normal ; two, having a depth of about $100 \mathrm{~km}$., occurred on January 23 and 24, and the third, depth $600 \mathrm{~km}$., on January 13 with an epicentre south of the Fiji Islands. It may be noted that no earthquake is so far known to have had its focus at a greater depth than $700 \mathrm{~km}$. All the earthquakes during the month occurred in well-known seismic areas, though the one on January 28 in the Atlantic Ocean some 1,100 miles east of Bermuda is not in an area from which earthquakes often occur. Observatory records have been received from the central stations of the United States Coast and Geodetic Survey and from Strasbourg, and from individual observatories at Beograd (Jugoslavia), De Bilt (Holland), Durham, Kew, Strasbourg, Stuttgart and Toledo (Spain)

Mekran (Baluchistan) Earthquake of November 28 ,

C. G. Pendsiy discussed all available data for the eartbgras at Mekran in Baluchistan on November 28, 7545 (Ind. Met. Dept., Sci. Not., 10, No. 125; 19.8 The epicentre was in the sea off the Mekran colst, and strength 10 on the Rossi-Forel scale was attained in the epicentral area. The instrumental magnitude was about $6 \cdot 7$, and the energy was of the order of $10^{21}$ ergs. The earthquake was attended by a seismic sea-wave which affected the whole of the Arabian seaboard. At Karwar, about 1,000 miles from the epicentre, the wave flooded the creeks and inlets, and boats anchored in the harbour were cut off from their moorings. There was serious loss of life and property at Pasni, the height of the second wave there being estimated at between 40 and $50 \mathrm{ft}$. At Karachi four distinct waves were distinguishable, and at Bombay a seismic sea-wave $6 \frac{1}{2} \mathrm{ft}$. high was experienced. It has been reported that two rocky oval islets, about three miles apart, appeared about the same time as the earthquake, some 180 miles west-south-west of Karachi. One islet rose about $30 \mathrm{ft}$. above the water and the other about $100 \mathrm{ft}$., the former having an area of about $1 \frac{1}{2}$ square miles and the latter about a square mile. Earthquakes have occurred in the past in the area off the Mekran coast on February 4, 1938, and January 7, 1940. Earthquakes on land near the point occurred on September 2, 1938, October 29, 1941, July 3, 1942, July 4, 1942, and February 6, 1943. Very strong 